\title{
Franklin Obeng-Odoom, Property, institutions, and social stratification in Africa, Cambridge University Press, Cambridge, 2020
}

\author{
Toyomu Masaki ${ }^{1} \mathbb{D}$
}

Received: 6 January 2021 / Accepted: 16 February 2021 / Published online: 28 February 2021

(c) Japan Association for Evolutionary Economics 2021

\begin{abstract}
Franklin Obeng-Odoom's book, Property, institutions, and social stratification in Africa (Cambridge University Press, 2020) challenges prevailing ideas on existing development policies and attempts to provide new alternative perspectives for more equitable economic development in Africa. The economic concepts on which the author relies for this purpose are stratification economics and the ideas of Henry George (1839-1897). In this review, after a brief introduction to these two frameworks, the contents of the book are presented. Next, the significance of the author's concepts is explained, and the reviewer's comments regarding the author's views are provided.
\end{abstract}

Keywords Global North and South · Henry George · Stratification economics · Land · Africa

JEL Classification $\mathrm{B} 1 \cdot \mathrm{N} 17 \cdot \mathrm{Z} 13$

\section{Introduction}

The author of the book Property, institutions, and social stratification in Africa (Cambridge University Press, 2020), Franklin Obeng-Odoom, is a political economist who was born in Ghana. His research interests are centered on the political economy of development, cities, and natural resources. As a scholar of sustainability science at the University of Helsinki, he has been working vigorously to produce scholarly works, including policy recommendations for pro-poor development in the global South.

Toyomu Masaki

tmasaki@staff.kanazawa-u.ac.jp

1 Kanazawa University, Kanazawa, Japan 
Throughout his new book, Franklin Obeng-Odoom vents his frustration with the theories that mainstream economics, especially those in the field of development economics, have relied upon in their attempts to address the poverty issues in his home continent, Africa. Specifically, property economics, land reform, economic growth, and international trade are the subjects of his criticism. The most prominent feature of this book is its provision of alternative systems from the perspective of stratification economics and the philosophies of Henry George (1839-1897), an American political economist active during the nineteenth century. In the context of these two frameworks, Obeng-Odoom first questions the existing explanations of the inequalities within Africa and between Africa and the rest of the world and then rejects the prevailing economic policies proposed by mainstream economics intended to address these issues. Next, he presents alternative strategies for the future development of African countries. The remainder of this review proceeds as follows: first, it briefly reviews stratification economics and the ideas of Henry George to provide a clear understanding of Obeng-Odoom's argument. Next, it presents the contents of the book, and this is followed by the reviewer's comments.

\section{Stratification economics and Africa}

Stratification economics became widely known through a keynote address delivered by William A. Darity Jr. in 2005 at the Annual Meeting of the Academy of Economics and Finance in Savannah, Georgia (Darity et al. 2015). This theory represents an important new approach to explaining economic inequality in terms of how social groups are separated or stratified (Davis 2015).

To illustrate this new theory, let me use some simple examples. Almost without exception, on average, men still earn more than women around the world. Furthermore, the US Bureau of Labor Statistics shows that the weekly average income of the white population tends to be higher than that of the Black or African American and the Hispanic and Latino populations. ${ }^{1}$ These outcomes are probably inseparable from the social structural factors that make it easier for white men to gain the necessary education and experience to obtain better occupational skills than other groups. Stratification economics directs attention to the causes and environments that lead to such outcomes by adopting a methodology developed in the field of sociology. In fact, the prevailing stereotypes in society can create this disadvantageous condition for minority groups. Furthermore, this biased structure has been passed down through numerous generations, and many of the gaps between vested interests and minorities have grown over time.

Stratification economics can also be useful in understanding the current inequality that exists between the global North and South. Darity himself proposed its application to investigate the international macroinequality between rich and poor nations by referring to the argument developed by Eric Williams in Capitalism and Slavery

\footnotetext{
1 US Bureau of Labor Statistics https://www.bls.gov/webapps/legacy/cpswktab3.htm (Date of access: 28 December 2020).
} 
(1944). Williams argued that slavery helped finance the Industrial Revolution in England and that the economic entities connected with the slave trade accumulated vast fortunes, enabling the establishment of banks and heavy industry in Europe. This phenomenon expanded the reach of capitalism worldwide and put Africa in a relatively inferior position. Darity (2005, p. 145) appreciated how William's (1944) work connected uneven development in the modern world to the impact of the modern slave trade, which informed the theory of stratification economics regarding the origins of global inequality. From the same perspective, Obeng-Odoom attempts to investigate African developmental issues in relation to factors that are external to the continent.

\section{Henry George and his philosophy}

Henry George (1839-1897) was an American political economist and reformer active during the late nineteenth century. In his book Progress and Poverty (1879, 2005), he proposed a single tax on land rents or, more precisely, a tax on income from the use of undeveloped (bare) land but not from improvements; additionally, he proposed the abolishment of all other taxes. He explained the purpose of this proposition as follows: The Duke of Westminster, who owns a considerable part of the site of London, is probably the richest landowner in the world. To take all his ground rents by taxation would largely reduce his enormous income, but would still leave him his buildings and all the income from them, and doubtless much personal property in various other shapes. He would still have all he could by any possibility enjoy, and a much better state of society in which to enjoy it (Henry Georgy $(1879,2005)$, p. 320). During the nineteenth century, advanced Western societies experienced rapid economic and population growth. Consequently, land prices also increased, and the widening gap between rich and poor people became a serious issue. In these circumstances, Progress and Poverty captured people's attention and became one of the bestselling books of the nineteenth century, and it still provides influential thoughts for modern times.

Above all, Henry George saw land monopolies as a detriment to society. He also questioned absentee landowners who obtained even greater returns through increasing land prices without contributing to improving land productivity. He believed that people should own the value that they produce but that the economic value derived from land should belong equally to all members of society. If the whole value of unimproved land was taxed, absentee landowners would have less incentive to hold their land, which could enable farmers to obtain land at less expensive prices.

The ideas of Henry George, which are collectively known as Georgism, became popular not only in Western societies but also in Asia. A Japanese translation of Progress and Poverty was published in 1892 and had a great impact on socialist movements in Japan before World War II. It is also widely known that Sun Yat-sen (1866-1825), the father of the Chinese Revolution (1911-1912) and a founder of the Chinese Republic, acknowledged Henry George's ideas. Moreover, he attempted to introduce the taxation of land based on self-assessed land values, under which the state would reserve the right to purchase land at these values and would impose an 
annual tax that reflected the land value on the owners (Lin 1974; Niou and Tan 1994; Schiffrin 1957; Trescott 1994). This policy was intended to equalize land ownership. Even though the political regime has changed to the Communist Party, private ownership of land is still prohibited in the present People's Republic of China.

For decades, transnational corporations (TNCs) have been eager to exploit the natural underground resources in Africa. Furthermore, in recent years, they have accelerated their investments in African land to secure food for the growing world population. The concentration of African land and resources in the hands of TNCs can rob Africans of their autonomy, impoverish the African people, and damage the environment of Africa. To avoid this situation, Obeng-Odoom suggests alternative actions based on Henry George's theorem.

\section{The presentation of the book}

The book consists of eight chapters, including the introduction and conclusion, and is divided into three parts: problems, problematic explanations and solutions, and alternatives.

Part I consists of the introduction (The Global South in a "Compartmentalized World") and Chapter 1 (Foundations for a New Beginning). The author argues that mainstream development economics not only fails to alleviate poverty but also performatively contributes to creating and maintaining the structures of inequality and poverty (p. 52). Next, the author explains the need to adopt the stratification economics approach to address poverty issues in Africa. Furthermore, the author shows his commitment to the ideas of Henry George, who argued that the economic rent of land should be shared by society (George 1879).

Part II comprises four chapters (Chapters 2 through 6). In each chapter, the author discusses one strategy that is often discussed in mainstream economics.

Chapter 2 focuses on property economics in relation to Africa's land reforms. Most of the land in sub-Saharan Africa has been (or was) governed under the customary tenure system, wherein the land is (or was) communally owned under the authority of traditional chiefs or is under the control of large families or clans. It is believed that this communal land ownership has not provided the necessary security to ensure agricultural investment and the protective use of land. It has also made it difficult for African entrepreneurs to borrow money from banks using land as their collateral. To address these issues, the necessity of establishing property rights has been widely recognized by development economists. Obeng-Odoom challenges this view and the work of a Peruvian economist, Hernando de Soto Polar, a representative advocate of this movement. In his book Mystery of Capital, Why Capitalism Triumphs in the West and Fails Everywhere Else (de Soto 2000), the author argues that institutionalizing individual private property such as land and housing encourages poor people to lift themselves out of poverty. His ideas have been supported by international organizations and Western donors. Opposing this reasoning, Obeng-Odoom first criticizes de Soto's (2000) framework by referring to Joseph Schumpeter, Karl Polanyi, and Henry George and then warns that the private 
ownership of land increases land prices and widens the gap between possessors and nonpossessors.

Chapter 3 sheds light on the land reform suggested by de Soto and initiated by the World Bank and the international community of African countries. This type of land reform has often caused land grabbing, namely, large-scale land acquisition, by global companies or foreigners. Due to global concerns regarding food security and fuel supplies, a large amount of funds poured into the African continent after the 2000s, increasing land prices and thereby creating a barrier to local farmers aiming to purchase land. After reviewing case studies in Ghana, South Africa, Uganda, and Egypt, Obeng-Odoom admits that the individualized system could be beneficial in terms of its emphasis on establishing clear boundaries and rights to clearly identifiable people (p. 116). However, he also points out that land reform is a tool for transferring African wealth to the rest of the world in ways that widen the many gaps related to development and underdevelopment (p. 117).

In Chapter 4, the author discusses the prevailing human capital formation strategy for resource-rich countries. This chapter begins by criticizing the view suggested by Thorvaldur Gylfason (2001), namely, that oil booms undermine human capital. This phenomenon is also known as a "resource curse." Obeng-Odoom flatly denies the validity of this view by describing cases in Ghana, where the demand for and supply of education have increased substantially after the country's transformation to an oil-producing country. He explains that the Local Content Law in Ghana encouraged international oil companies to support the supply of both education and experience to Africans with the aim of "catching up" to developed countries. He calls this approach libertarian paternalism. However, Obeng-Odoom does not appear to be satisfied with the outcomes of these policies because the ensuing employment levels and returns on employment have been substantially lower than expected and different from what was predicted by using the orthodox theory of human capital. In reality, Africans are concentrated in the low-paying, low-tier positions of foreign firms, while expatriate staff enjoy much better working conditions. Additionally, the development of the oil industry creates pollution in the atmosphere and corruption in society. The author concludes that the use of the human capital formation strategy in a mineral-based society embodies many socioeconomic contradictions and that increased education and experience have led to widening, not declining, social stratification in Africa.

Although Chapter 5 is entitled International Trade, it covers various subjects related not only to imports and exports but also to international financial systems, transnational corporations, urbanization, and local governance. Mainstream economics has emphasized that the economic liberalization that attracts TNCs will contribute to creating an innovative society and technological development in the South. In contrast, Obeng-Odoom is persuaded that this liberal economic concept has impoverished Africa and widened the urban-rural gap. Nevertheless, he rejects protectionism policy, unlike Structuralists and Marxists. At this point, the author again demonstrates his consensus with Henry George, who supported the free trade system under certain conditions as well as the imposition of taxes on land. The argument that is used to support land taxation is that land should be a common good for all and that people should have an exclusive right to its use and to the 
enjoyment of the products of their own labor. The latter part of this chapter turns to concerns about the recent dominance of TNCs over local companies in terms of the urban infrastructure in Africa. According to mainstream economics, the activities of TNCs involve local human capital improvement. However, the author criticizes this view because TNCs often leave people with no education or leave those with outdated education behind, and they contribute to creating environmental pollution. He explains that the people of Africa are powerless before TNCs and find it difficult to demand accountability of them. The author concludes that international trade is a mechanism for creating social stratification.

Chapter 6 is entitled Economic Growth, but the author's interests are directed more toward the negative effects of economic growth than toward economic growth itself. In fact, the real GDP of sub-Saharan African countries generally increased between the early 2000s and the beginning of the 2010s, and Africa was thought of as an emerging continent of hope. However, along with the decrease in natural resource prices after the mid-2010s, Africa's economic growth has also been slowing down, and many African governments are now suffering from accumulated debt. Even during prosperous times, increasing economic inequality, the deterioration of the environment, and social conflicts have been critical issues in many African countries. The author emphasizes that these concerns are occurring in the shadow of the "Africa is on the rise" discourse. He concludes that the policy of opening up domestic resources to foreign investors leads to a crisis in the economy, society, and the environment, as these profit-led growth policies often "drive to maximize profit, to cut costs, to produce more with less and at high speed, and to prioritize profits over environment and society" (p. 215).

Finally, in Part III, Obeng-Odoom suggests two alternatives: Socialisms (Chapter 7) and Africanisms (Chapter 8). According to the author, capitalism is "a system based on exploitation, wage theft, burn out, rent theft, plunder, and ecological crises on a world scale", and "socialism promises a link between a more social world and the good society" (p. 219). However, he is not advocating for socialism as it existed in the past. In fact, during the postcolonial era, many African countries joined the world led by the USSR and the People's Republic of China, but none succeeded in their economic development. What Obeng-Odoom is proposing is a transformation of the capitalist system from within (p. 234). In fact, Henry George, whom the author admires, is also known as a supporter of free trade. Regarding land issues, he emphasizes that the mere physical redistribution of land, which is often demanded by Marxists in Africa, has never eliminated absentee owners who like to own land just for rent, which causes social stratification. Therefore, the author proposes socializing these land rents by increasing the taxes imposed on them "to address not just inequality but also systemic inequality". The author alleges that Africa's underdevelopment is the product of cumulative change and the outcome of ongoing contradictions and exploitation related to trade, debt, and land reforms. Thus, the author suggests that breaking up the cartels and monopolies is a key step in addressing these issues, and he calls the collection of strategies needed to achieve this aim in African society Africanisms or African socialisms. Unlike some Marxist programs in the past, the author supports gradual, progressive, and systematic reforms as advocated by other Georgists. 


\section{Contribution and future expectations regarding the Author's achievement}

Property, institutions, and social stratification in Africa is probably the first book to address African development strategies under the two frameworks of stratification economics and Henry George's theorem. The author seeks to persuade his readers that the historical experiences of this continent, such as the slave trade, colonial rule, and its external relations during the postcolonial era, have placed African countries in a structurally disadvantaged position. He voices his concerns that this hindrance will cause further widening of the intergroup inequality in Africa, as well as of the inequality between Africa and the rest of the world, if the prescriptions of mainstream development economics are followed. As alternative strategies, he presents Africanisms and a new form of socialisms that are different from the strategies applied by African countries in the past. While it is uncertain whether Obeng-Odoom's suggestions could be accepted and implemented in a concrete way, he successfully presents a new way of thinking when addressing developmental issues in Africa. In fact, Africa has not been able to achieve its desired outcomes despite its various efforts toward economic development. Therefore, it must be true that some kind of paradigm shift is required.

Despite these arguments, I question whether Henry George's theorem is still applicable in the contemporary world, which requires the provisions of much more advanced infrastructures than those existing in the era of Henry George. In this case, the rents from undeveloped (bare) land account for only a tiny fraction of those from the entire land, implying that the rents that society can share by imposing taxes on undeveloped land become very small compared to the size of the entire economy. Furthermore, barring a limited number of countries with attractive conditions, this era of globalization would require that many countries adopt Henry George's ideas together. Otherwise, since investors, including domestic investors, would tend to avoid devoting their capital to countries that impose unique bothersome requirements, the economic development of a country that uniquely adopted Henry George's idea could be hindered.

While pondering his arguments, it suddenly occurred to me there is a country that overcame its poverty and became the world's second largest economy by adopting strategies similar to those proposed by Obeng-Odoom. The People's Republic of China advocates for socialism but also exhibits very capitalistic characteristics, and it has promoted its own path for realizing drastic economic growh that is quite different from the Western system. The Chinese government strictly controls the business of foreign companies on its soil and prohibits its national citizens from using some of the Internet services provided by American Big Tech companies. The private ownership of land is also not allowed. Given the example of China's dramatic success in reducing poverty during the 20 years between 2000 and 2020, Obeng-Odoom's suggestions may not be far off the mark for realizing pro-poor development in Africa. However, contrary to his expectation, it should be noted that the gap between the rich and poor in China has temporarily widened significantly. According to the World Bank, the Gini coefficient in China 
drastically increased from 32.2 (1990) to 43.5 (2010), though it has recently decreased to 38.5 (2016). ${ }^{2}$ Moreover, unlike most African countries, China has a massive domestic market, which has allowed it to form an industrial base by applying import substitution industrialization strategies. However, it would likely be difficult for African countries, whose markets have fewer than 50 million people, to use the same method.

Furthermore, a very strong or coercive regime may be needed to implement the paradigm shift suggested by Obeng-Odoom. Although he has never condoned undemocratic means, it would be unrealistic to expect the government to have great power only in the area of the economy. We already know that such a coercive regime always carries the risk of incidents, such as have actually occurred in Tibet, Hong Kong, and the Xinjiang Autonomous Region. Moreover, it should be noted that China's current involvement within the African continent is astonishing. China has helped African countries since the 1950s when China itself was receiving official development assistance (ODA) from developed countries. African students who were hosted by China are now serving as national officers or elites in their home countries. During the twenty-first century, it may be possible for the Chinese system to replace the current development strategy criticized by Obeng-Odoom in his book, although I cannot say which is better.

It is undeniable that the current economic development model and actual global economic system have some flaws. The issues of environmental destruction and climate change are becoming increasingly serious, and their long-term economic impacts cannot be overlooked. Africa is a primary victim of these flaws. The recent coronavirus pandemic also reveals the importance of the public sector's role in the market system. I sympathize with the author's frustration at the current situation in which a part of citizens on his home continent is being increasingly impoverished by the global economic system. However, if the author intends to appeal to a wide audience and wants to change-in even the slightest way - the direction of the currently dominant development policy, it might be necessary to present his ideas in a way that is more understandable to the general public. Both stratification economics and Henry George's theorem may already be well-known subjects among political and institutional economists. However, I wonder how many policymakers or bureaucrats who are actually engaged in development programs in Africa are familiar with these theories and able to follow his arguments and read the entire 364-page book. Perhaps a simpler style of writing and more reader-friendly arguments could deliver his message more clearly to a wider audience, including to nonnative English speakers, and thereby more effectively gain support of his vision.

\section{References}

Darity W (2005) Stratification economics: the role of intergroup inequality. J Econ Finance 29(2):144152. https://doi.org/10.1007/BF02761550

\footnotetext{
2 The World Bank Indicator https://data.worldbank.org/indicator/ (Date of access: 28 December 2020).
} 
Darity W, Hamilton D, Stewart JB (2015) A tour de force in understanding intergroup inequality: an introduction to stratification economics. Rev Black Polit Econ 42(1-2):1-6. https://doi.org/10.1007/ s12114-014-9201-2

Davis JB (2015) Stratification economics and identity economics. Camb J Econ 39(5):1215-1229. https:// doi.org/10.1093/cje/beu071

De Soto H (2000) The mystery of capital: why capitalism triumphs in the West and fails everywhere else. Bantam, London

George H $(1879,2005)$ Progress and poverty: an enquiry into the cause of industrial depressions, and of increase of want with increase of wealth. Cosimo, Inc., New York, NY

Gylfason T (2001) Natural resources, education, and economic development. Eur Econ Rev 45(4-6):847859. https://doi.org/10.1016/S0014-2921(01)00127-1

Lin S (1974) Sun Yat-sen and Henry George: the essential role of land policy in their doctrines. Am J Econ Sociol 33(2):201-220. https://doi.org/10.1111/j.1536-7150.1974.tb02456.x

Niou EM, Tan G (1994) An analysis of Dr. Sun Yat-sen's self-assessment scheme for land taxation. Public Choice 78(1):103-114. https://doi.org/10.1007/BF01053368

Schiffrin H (1957) Sun Yat-sen's early land policy: the origin and meaning of "equalization of land rights.” J Asian Stud 16(4):549-564. https://doi.org/10.2307/2941638

Trescott PB (1994) Henry George, Sun Yat-Sen and China: more than land policy was involved. Am J Econ Sociol 53(3):363-375. https://doi.org/10.1111/j.1536-7150.1994.tb02606.x

Williams E (1944) Capitalism and slavery. University of North Carolina Press, Chapel Hill, NC

Publisher's Note Springer Nature remains neutral with regard to jurisdictional claims in published maps and institutional affiliations. 